\title{
Effects of Temperature on the Occurrence of Bitter Fruits and Nitrogen Contents in Leaves of Cucumber (Cucumis sativus L., cv. Kagafutokyuri)
}

\author{
Yasutaka Kano, Hideyuki Goto, Hidenori Fukuda* and Kenji Ishimoto* \\ Ishikawa Agricultural College, Nonoichi, Ishikawa 921-8836, Japan \\ ${ }^{*}$ Kanazawa Agriculture Center, Kanazawa 920-0371, Japan
}

(Received August 3, 1999)

\begin{abstract}
The occurrence of bitter fruit in cucumber (Cucumis sativus L., cv. Kagafutokyuri) was higher in the plots with a lower air temperature (the early growing stage and the non-heating treatment). Leaf weight was smaller in the plots with a lower air temperature. Total-N, amino acid-N and protein contents were higher or showed a tendency to be higher in the plots with a lower air temperature. Nitrate-N content was higher in the early growing stage than in the later one, while it was higher in the heating treatment than the non-heating.
\end{abstract}

\section{INTRODUCTION}

'Kagafuto' kyuri Cucumis sativus L. is mainly cultivated in Kanazawa City of Ishikawa Prefecture. The cucumbers are harvested when they weigh about $800 \mathrm{~g}$ (Fig. 1) and prepared in salads or dishes with a liquid starch dressing (Kano et al., 1997a). Bitter fruits frequently occur from April to May in the semi-forcing culture. Twelve kinds of bitter principles, explaining the development of bitterness, are found in plant organs of 46 species in Cucurbitacea (Rehm et al., 1957), while cucurbitacin C is recognized only in C. sativus L. (Enslin and Rehm, 1958). From the reports it can be considered that the bitter principle in cv. Kagafutokyuri is also cucurbitacin C. On the other hand, it is revealed that cucurbitacin $\mathrm{C}$ is synthesized from acetyl-CoA via mevalonic acid to squalene, and a lot of enzymes are related to the pathway of synthesis of cucurbitacin C (Balliano et al., 1983a, b).

In the experiments of comparisons of nitrogen contents in the leaves and fruits between a non-bitter line and a bitter line, the contents of total and amino acid nitrogen are much higher in the bitter leaves and fruits, and the contents in leaves were higher in the bitter line than in the non-bitter line (Kano et al., 1999). Consequently, it is suggested that high total nitrogen and amino acid-nitrogen contents induce bitterness in leaves and fruits by promoting nitrogen metabolism, which in turn favors the enzymatic synthesis of cucurbitacin $\mathrm{C}$, the bitter factor.

On the other hand, the development of bitterness in the cucumber fruit is affected by a sudden drop of night temperatures and a sudden rise of day temperatures (Enslin et al., 1954). From the experience of producers of cv. Kagafutokyuri, it is surmised that one of the reasons for the high occurrence of bitter fruit in cv. Kagafutokyuri from middle of April to early of May is the lower air temperature.

Therefore, to elucidate the effects of low air temperature on the occurrence of bitter fruit 
in cv. Kagafutokyuri (C. sativus L.), in this paper the relationship between the occurrence and leaf nitrogen content was investigated in plants grown under different air temperatures.

\section{MATERIALS AND METHODS}

Experiment 1: Comparison of the occurrence of bitter fruit and leaf nitrogen levels between the early growing stage and the later one. Seeds of the bitter line were sown on the 25th of January, 1997. The nursery plants grafted on Cucurbita ficifolia Bouché were planted on the 10th of March in the non-heated greenhouse, where the amounts of $22 \mathrm{~g} \mathrm{~m}^{-2}$ of N, 28 $\mathrm{g} \mathrm{m}^{-2}$ of $\mathrm{P}_{2} \mathrm{O}_{5}$ and $22 \mathrm{~g} \mathrm{~m}^{-2}$ of $\mathrm{K}_{2} \mathrm{O}$ were applied as basal fertilizers and the amount of $18 \mathrm{~g} \mathrm{~m}^{-2}$ of $\mathrm{N}$ as side dressing at intervals of $10 \mathrm{~d}$ from the 4th of April. As the main shoot was pinched off, the first lateral shoots acted as the main stems; shoots of the new main stems were secondary lateral shoots. The first lateral shoots acting as the main stems were pinched off at around the 20th node. The secondary lateral shoots were also pinched off, leaving one node. Fruit borne on the first lateral shoot was sampled for determining bitterness, from the 29th of April to the 6th of May (designated as the early growing stage) and from the 23rd of May to the 31st of May (designated as the later growing stage), and whether it was non-bitter fruit or bitter fruit was determined by biting the opposite side from the calyx end. Fifteen plants were employed in each treatment. Leaf weight and leaf color were measured on the 6th of May and on the 5th of June for the early and later growing stages, respectively. Leaf color was checked by using SPAD-501 (MINOLTA Inc.). Leaves borne on the second (lower node leaf), the 10th (middle node leaf) and the 19th (upper node leaf) nodes were sampled, and prepared for the determination of nitrogen contents as in Experiment 3. Ten plants were employed in each treatment.

Daily minimum air temperatures were measured from the 7 th of April to the 31 st of May, and average temperature for $5 \mathrm{~d}$ was calculated. The highest and lowest daily minimum air

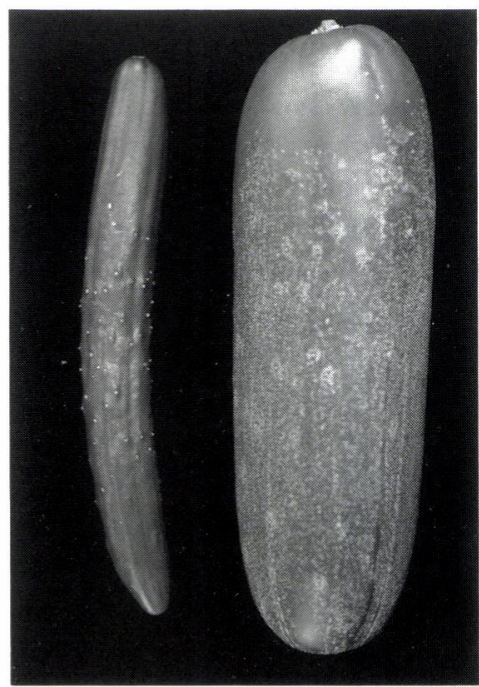

Fig. 1 Fruits of Cucumis sativus L., cv. Sharp Seven (common cucumber, left) and cv. Kagafutokyuri (right) harvested at about 100 and $800 \mathrm{~g}$, respectively.

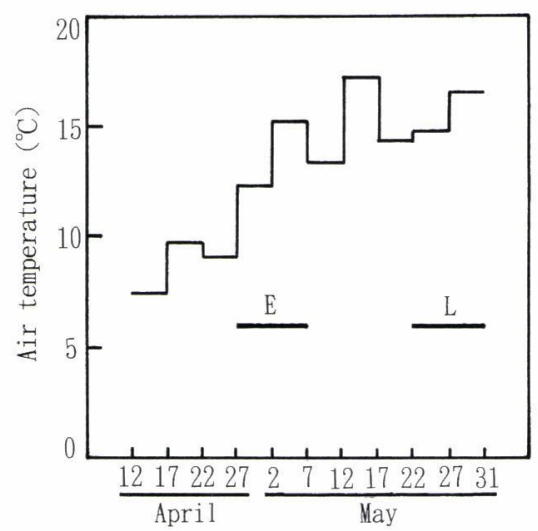

Fig. 2 Changes in minimum air temperature during growing period.

The early growing stage (E) and the late growing stage (L) show the period where the bitterness of the fruits were investigated. 
temperature was 12.6 and $7.3^{\circ} \mathrm{C}$, and 16.5 and $13.3^{\circ} \mathrm{C}$ in the early growing stage and the later one, respectively (Fig. 2).

Experiment 2: Comparison of the occurrence of bitter fruit and leaf nitrogen levels between the heated greenhouse and the non-heated one. Seeds of a bitter line were sown on the 25th of January, 1998. The nursery plants grafted on C. ficifolia Bouché were planted in the heated greenhouse (designated as the heating treatment) and were planted in the nonheated one (designated as the non-heating treatment) on the 10th of March. They were raised in the same manner as in Experiment 1. The fruits sampled from the 17th of April to the 2nd of May were determined to be non-bitter or bitter as in Experiment 1. Fifteen plants were employed. Leaf weight and color were investigated on the 29th of April as in Experiment 1, and prepared for measurement of nitrogen content as in Experiment 3. Ten plants were employed. The heating for the greenhouse began on the 10th of March, and ended on the 2nd of May.

Daily minimum air temperature was measured from the 2nd of April to the 2nd of May, and average ones during $5 \mathrm{~d}$ were calculated. While average minimum air temperature of the heating treatment was above $13.8^{\circ} \mathrm{C}$, the minimum air temperature of the non-heating treatment was under $12^{\circ} \mathrm{C}$ nearly the entire growing period (Fig. 3).

Experiment 3: The quantitative analysis of nitrogenous compounds. Sampled leaves were dried at $80^{\circ} \mathrm{C}$ for $1 \mathrm{~d}$ and $60^{\circ} \mathrm{C}$ for $2 \mathrm{~d}$, and ground for analysis of total nitrogen (total-N), nitrate nitrogen (nitrate-N), amino acid nitrogen (amino acid-N) and protein, using the $\mathrm{CN}$ analyzer (Sumitomo Chemicals Ltd.), Cataldo's method, ninhydrin reaction and the Bradford method, respectively.

\section{RESULTS}

Experiment 1: Comparison of the occurrence of bitter fruit and leaf nitrogen contents between the early and the later growing stages

The occurrence of bitter fruit was high, $65 \%$, for the early growing stage, as compared with

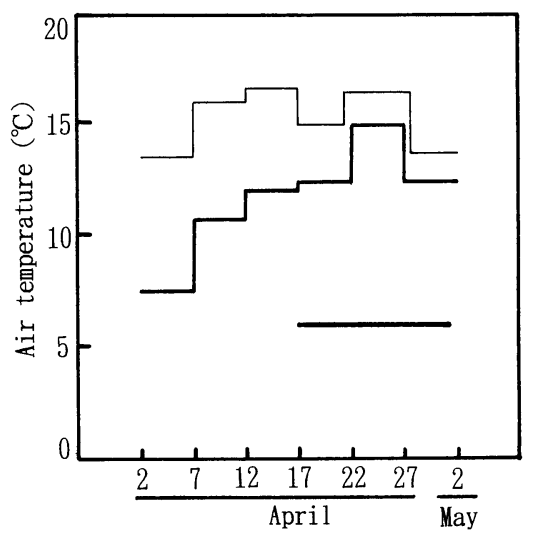

Fig. 3 Comparison of average minimum air temperature for $5 \mathrm{~d}$ between the heated greenhouse (fine line) and the nonheated one (bold line).

The bold horizontal line in the figure shows the period where the bitterness of fruits was investigated.

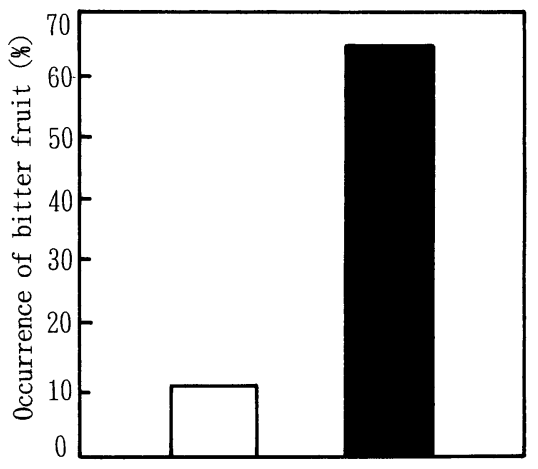

Fig. 4 Comparison of the occurrence of bitter fruit between the late growing stage ( $\square)$ and the early growing one 


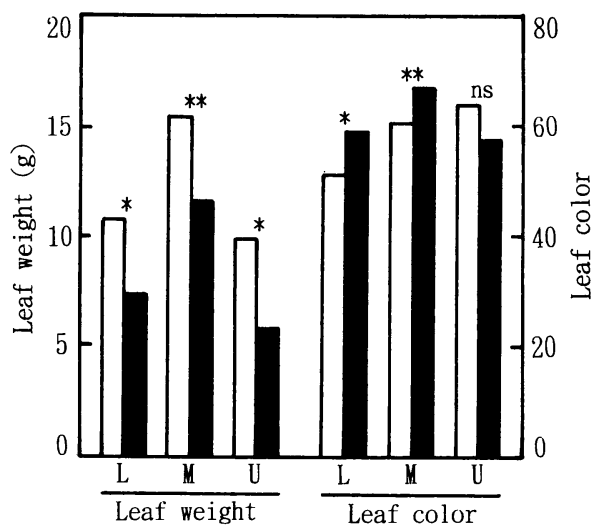

Fig. 5 Comparison of leaf weight and color between the late growing stage ( $\square$ ) and the early growing one ( $\square$ ).

$\mathrm{L}, \mathrm{M}$ and $\mathrm{U}$ show the lower, middle and upper nodal leaf, respectively. ns indicates nonsignificant difference, and * and **, significant differences at $p=0.05$ and $p=0.01$, respectively.

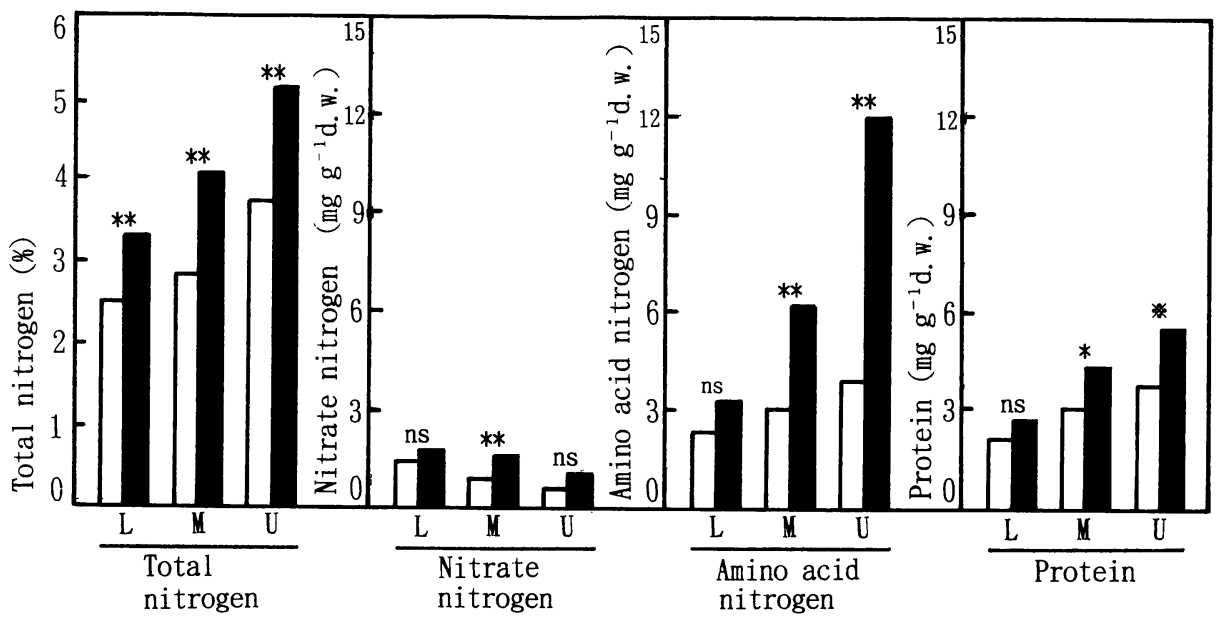

Fig. 6 Comparison of leaf total nitrogen, nitrate nitrogen, amino acid nitrogen and protein contents between the late growing stage $(\square)$ and the early growing one ( $\square$ ).

$\mathrm{L}, \mathrm{M}$ and $\mathrm{U}$ show the lower, middle and upper nodal leaf, respectively. ns indicates nonsignificant difference, and $*, *$ and $* *$, significant differences at $p=0.1, p=0.05$ and $p=0.01$, respectively.

$11 \%$ for the later one (Fig. 4). Leaf weight was smaller in the early growing stage than in the later one (Fig. 5). Leaf color was darker in the former than in the latter (Fig. 5).

Total-N content in each nodal leaf was $0.88 \%$ and larger in the early growing stage than in the later one (Fig. 6). Nitrate-N content was about $0.2 \mathrm{mg} \mathrm{g}^{-1} \mathrm{~d}$.w. higher in the lower and upper nodal leaves, and more than 2 times higher in the middle nodal leaves of the early growing stage than the later one (Fig. 6). Amino acid-N was $0.9 \mathrm{mg} \mathrm{g}^{-1} \mathrm{~d}$.w. higher in the lower nodal and more than 2 times higher in the middle and upper nodal leaf of the early growing stage than the later one (Fig. 6). Protein content was $2.5,4.0$ and $5.3 \mathrm{mg} \mathrm{g}^{-1} \mathrm{~d} . \mathrm{w}$. in 
the lower, middle and upper nodal leaf of the early growing stage, which was $0.3,0.8$ and 1.5 $\mathrm{mg} \mathrm{g}^{-1}$ d.w. higher than that of the later one, respectively (Fig. 6).

Experiment 2: Comparison of the occurrence of bitter fruit and leaf nitrogen contents between the heated greenhouse and non-heated one

The occurrence of bitter fruit was $42.9 \%$ for the non-heating treatment as compared with $0 \%$ for the heating treatment (Fig. 7). Leaf weight in the upper and middle nodes in the

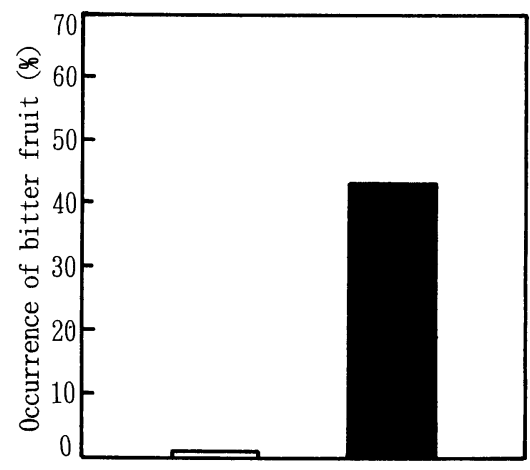

Fig. 7 Comparison of the occurrence of bitter fruit between the heated greenhouse ( $\square$ ) and the non-heated one

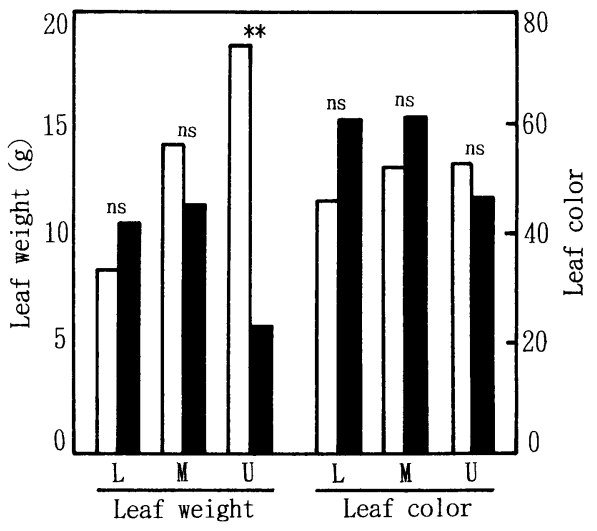

Fig. 8 Comparison of leaf weight and color between the heated greenhouse $(\square)$ and the non-heated one ( $\boldsymbol{\square})$.

$\mathrm{L}, \mathrm{M}$ and $\mathrm{U}$ show the lower, middle and upper nodal leaf, respectively. ns indicates non-significant difference, and

$* *$, significant difference at $p=0.01$.

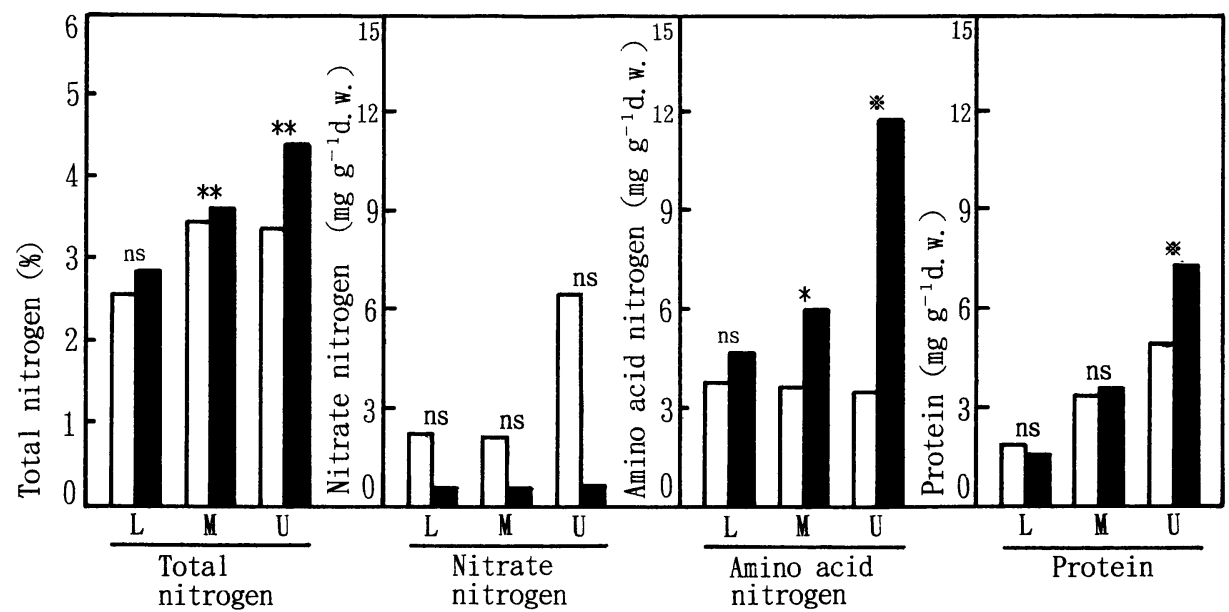

Fig. 9 Comparison of leaf total nitrogen, nitrate nitrogen, amino acid nitrogen and protein contents between the heated greenhouse $(\square)$ and the non-heated one ( $\square$ ).

$\mathrm{L}, \mathrm{M}$ and $\mathrm{U}$ show the lower, middle and upper nodal leaf, respectively. ns indicates nonsignificant difference, and $* *$ and $* *$, significant difference at $p=0.1, p=0.05$ and $p=0.01$, respectively. 
non-heating treatment was 5.7 and $11.2 \mathrm{~g}$, which was 12.7 and $2.8 \mathrm{~g}$ smaller than that for the heating treatment (Fig. 8). Leaf color in the lower and middle nodes for the non-heating was higher than that for the heating treatment (Fig. 8).

Total-N content in all the leaves was more than $0.2 \%$ higher in the non-heating treatment than in the heating (Fig. 9). However, nitrate-N in all the leaves was more than $0.8 \mathrm{mg} \mathrm{g}^{-1}$ d.w. lower in the non-heating than in the heating (Fig. 9). Amino acid content was 4.6, 6.0 and $11.8 \mathrm{mg} \mathrm{g}^{-1} \mathrm{~d} . \mathrm{w}$. in the lower, middle and upper nodal leaves for the non-heating treatment, which was $0.8,2.4$ and $8.4 \mathrm{mg} \mathrm{g}^{-1} \mathrm{~d}$.w. higher than that for the heating, respectively (Fig. 9). Protein content was 4.6 and $8.2 \mathrm{mg} \mathrm{g}^{-1} \mathrm{~d}$.w. in the middle and upper nodal leaves for the non-heating treatment, which was 0.5 and $3.5 \mathrm{mg} \mathrm{g}^{-1} \mathrm{~d}$.w. higher than that for the heating (Fig. 9).

\section{DISCUSSION}

In Experiments 1 and 2, the occurrence of bitter fruit was higher in the early growing stage and the non-heating treatment in plots with a lower air temperature.

Leaf weight was smaller and average minimum air temperature was $12^{\circ} \mathrm{C}$ and below in plots with a lower air temperature. Leaf enlargement in cucumbers is suppressed in an air temperature of $17^{\circ} \mathrm{C}$, as compared to $25^{\circ} \mathrm{C}$ (Kato, 1964). Furthermore, in the comparison of the leaf area of cucumbers at temperatures of $12,18,24$ and $30^{\circ} \mathrm{C}$ respectively, the relative rate of expansion of the leaf area increased with temperatures up to $24^{\circ} \mathrm{C}$ (Milthorpe, 1959). Consequently, it is suggested that leaf growth was suppressed by lower air temperature in plots with a lower air temperature.

In this experiment, root growth must be suppressed in plots with a lower air temperature, judging from the fact that root weight is smaller in the non-heating treatment (Kano et al., 1997b). In calculating the data of the results reported by Kano et al. (1995), the ratio of leaf weight to root one is lower in the plants with higher occurrence of bitter fruit. Accordingly, in this experiment, it can be also considered that the ratio of leaf weight to root one becomes smaller owing to much more suppressed leaf growth than root one in plots with a lower air temperature. Summing up these results, bitter fruits are considered to occur more frequently under the lower air temperature where the ratio of leaf weight to root one becomes smaller.

Total-N content was higher in plots with a lower air temperature. As absorption of nitrogenous compounds is closely related to root weight (Inada and Baba, 1958), the total amount of absorbed nitrogenous compounds must be smaller in the plots with a lower air temperature owing to smaller root weight. Therefore, it is reasonable to conclude that high total-N content in the leaves of the plot with a lower air temperature is caused by much more suppressed expansion of the leaf by lower air temperature. Furthermore, the darker color in the leaf with a high total-N content in this experiment coincides with the fact that leaf color corresponds to leaf nitrogen contents in the leaf (Bonner and Galston, 1952).

Nitrate- $\mathrm{N}$ content tended to be higher in the early growing stage than in the later one, while it was inclined to be higher in the heating treatment than in the non-heating one. Cucumbers are one of the nitrate-favoured plants (Ikeda and Osawa, 1979). Absorbed nitrate- $\mathrm{N}$ is transformed into amino acids through the nitrate reductase in the leaf (Webster, 1955). Nitrate-N subsisted at a higher content in the early growing stage, because of too much nitrate- $\mathrm{N}$ absorbed, which is inferred from high total $\mathrm{N}$ content (lower, 3.3\% ; middle, $4.1 \%$; upper, 5.1\%), even with active nitrate reduction occurring in the leaf. On the other hand, nitrate- $\mathrm{N}$ subsisted at a lower content in the non-heating treatment because of not so much nitrate- $\mathrm{N}$ absorbed, which is inferred from low total $\mathrm{N}$ content (lower, $2.8 \%$; middle, 3.7\%; upper, $4.4 \%)$. Thus, the inconsistency of higher nitrate-N contents in the early growing stage 
and lower ones in the non-heating treatment may be due to the differences of the total quantity of nitrate- $\mathrm{N}$ absorbed in the plants of two plots.

Amino acid-N level was higher in plots with a lower air temperature. This is the result of active reduction of nitrate- $\mathrm{N}$ and smooth amino acid formation (Webster, 1955) due to higher nitrate- $\mathrm{N}$ contents in plots with a lower air temperature.

Protein content showed a tendency to be higher in plots with a lower air temperature. As mentioned by Webster (1955), it is also considered that higher protein contents of the plots results from the active incorporation of the accumulated amino acids of the cells into proteins.

Consequently, we concluded as the following. In the leaf of the plant with a higher occurrence of bitter fruit under the condition of a lower air temperature, total nitrogenous contents become high owing to the suppression of leaf growth by lower air temperature, which provokes the active formation of amino acids and proteins, and the bitter principle.

This study was partly supported by a Grant-in-Aid for Scientific Research B 11460017 from the Ministry of Education, Science, Sports and Culture of Japan. The authors would like to thank Prof. eméritus Shunji Mukai of Kanagawa University for his critical reading of this manuscript.

\section{REFERENCES}

Balliano, G., Caputo, O., Viola, F., Delprino, L., Cattel, L. 1983a. The transformation of $10 \alpha$-cucurbita5,24-dien-3 $\beta$-ol into cucurbitacin $C$ by seedlings of Cucumis sativus. Phytochemistry 22 : 909-913.

Balliano, G., Caputo, O., Viola, F., Delprino, L., Cattel, L. 1983b. Cyclization of squalene-2,3-epoxide to $10 \alpha$-cucurbita-5,24-dien-3 $\beta$-ol by microsomes from Cucurbita maxima seedlings. Phytochemistry 22 : $915-921$.

Bonner, J., Galston, A. W. 1952. Photosynthesis. In "Principles of Plant Physiology." W. H. Freeman and Co., San Francisco, p 11-45.

Enslin, P. R., Jourbert, T. G., Rehm, S. 1954. Bitter principles of the Cucurbitaceae. Part II. Paper chromatography of bitter principles and some application in horticultural research. J. South Afr. Chem. Inst. 7(2): 131-138.

Enslin, P. R., Rehm, S. 1958. The distribution and biogensis of the cucurbitacines in relation to the taxonomy of the Cucurbitaceae. Proc. Linn. Soc. Lond. 69: 230-238.

Ikeda, H., Osawa, T. 1979. Comparison of adaptability to nitrate source among vegetable crops. I. Growth response and nitrogen assimilation of fruit vegetables cultured in nutrient solution containing nitrate, ammonium, and nitrite nitrogen. (Japanese text with English abstract) J. Jpn. Soc. Hortic. Sci. 47 : 454-462.

Inada, K., Baba, T. 1958. Physiological and ecological studies of paddy rice root. Relationship between some characteristics of paddy rice root and nutrient absorption. (Japanese text) J. Agric. Sci. 13 : 289-293.

Kano, Y., Yamabe, M., Ishimoto, K., Kameda, H. 1995. Effects of stocks on the occurrence of bitter fruit in Kagafutokyuri (Cucumis sativus L.). (Japanese text) J. Jpn. Soc. Hortic. Sci. 64 (Suppl. 2) : 306307.

Kano, Y., Yamabe, M., Ishimoto,K. 1997a. The occurrence of bitter cucumber (Cucumis sativus L. cv. Kagafutokyuri) in relation to pruning, fruit size, plant age, leaf nitrogen content and rootstock. (Japanese text with English abstract) J. Jpn. Soc. Hortic. Sci. $66: 321-329$.

Kano, Y., Yamabe, M., Fukuda, H. 1997b. Effect of heating and ethrel treatments on the occurrence of bitter fruit of cv. Kagafutokyuri. (Japanese text) J. Jpn. Soc. Hortic. Sci. 66 (Suppl. 2) : 418-419.

Kano, Y., Yamabe, M., Ishimoto, K., Fukuda, H. 1999. The occurrence of bitterness in the leaf and fruit of cucumbers (Cucumis sativus L. cv. Kagafutokyuri) in relation to their nitrogen levels. (Japanese text with English abstract) J. Jpn. Soc. Hortic. Sci. 68 : 391-396.

Kato, T. 1964. Relationship between the growth of fruit vegetables and air and soil temperature during the raising seedlings. (Japanese text) Agric. Hortic. 39: 1135-1136.

Milthorpe, F. L. $\quad$ 1959. Studies on the expansion of the leaf surface. I. The influence of temperature. J. 
Exp. Bot. 10 : 233-249.

Rehm, S., Enslin, P. R., Meeuse, A. D. J., Wessels, J. H. 1957. Bitter principles of the Cucurbitaceae. VII.

The distribution of bitter principles in this plant family. J. Sci. Food Agric. 8 : 679-686.

Webster, G. C. 1955. Nitrogen metabolism. Ann. Rev. Plant Physiol. 6 : 43-70.

\section{〈和文抄録〉}

\section{‘加賀太’キュウリの葉および果実における苦味発現と窒素レベルとの関係} ならびに苦味果の発生と窒素レベルに及ぼす低温の影響

\section{加 納恭卓・後藤秀幸・福田秀範*・石本兼治*}

\section{石川県農業短期大学, ${ }^{*}$ 金沢市農業センター}

加賀太キュウリ（Cucumis sativus L.）における苦味果の発生と葉中の窒素レベルに及ほす低温 の影響について調査した. 低温条件下で生育したキュウリでは, 葉重はより小さくなり, 苦味果の 発生は高くなった. 葉中の硝酸態窒素含有率は一定の傾向が認められなかったが, 葉中の全窒素, アミノ酸，タンパク質含有率は，低温条件下でより高くなる傾向が認められたししだって，低温 下では植物体の葉の生長が著しく抑制される結果, 葉中の全窒素含有率が高まり, 硝酸還元が活発 に行われ，アミノ酸，タンパク質の生合成，苦味の発現が促進されるものと考えられる. 